\title{
Telehealth in audiology: an integrative review
}

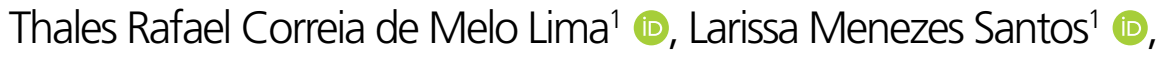 \\ Marcella Cristina Halliday Muniz ${ }^{1}$, Brenda Carla Lima Araújo²* (1), \\ Mario Adriano dos Santos ${ }^{3}$, Adicinéia Aparecida de Oliveira ${ }^{1,4} \mathbb{1}$, Silvia de Magalhães Simões ${ }^{1,3}$
}

\section{SUMMARY}

We performed an integrative review on the scientific literature about the use of telehealth in audiology care. Through high criteria search of published studies on the "Biblioteca Virtual em Saúde" - Virtual Health Library, PubMed, and Scientific Electronic Library Online databases, nine articles were selected. It was possible to verify that the use of telehealth in audiology is feasible and efficient, because it could promote audiological care for patients from away places. This process reaches more patients and communities by breaking down geographic barriers, and it offers a specific service not available with less cost and more quickly when compared with traditional speech therapy care.

KEYWORDS: Telehealth. Healthcare. Telemedicine. Audiology. eHealth.

\section{INTRODUCTION}

Telehealth is defined as the provision of health care services, such as consultancy, monitoring, prevention, and treatment of diseases, through the use of information and communications technology (ICT) ${ }^{1}$. It is a term used interchangeably with telemedicine, eHealth, and digital health, and it can be considered as a strategy to mitigate problems related to the shortage of professionals in remote areas, as well as the need for training professionals in that regions and consequent improvement in health care provided by them ${ }^{2}$.

In a systematic review of public investment in telehealth actions, Celes et al. ${ }^{3}$ identified the use of this strategy in different actions, such as continuing education programs for health professionals, expansion of health care access with reduced costs in remote areas, collaboration in hospital care and palliative care, care of bedridden patients with limited mobility, strengthening primary health care, improvement of health record systems, and the planning of other relevant actions and services.
In Brazil, the use of telehealth services has been implemented since mid-2007, aiming to support Primary Care all over the country through the Sistema Único de Saúde (SUS) - Unified Health System. The program "Telessaúde Brasil Redes" provides teleconsulting services, telediagnostics, teleducation, and formative second opinion to SUS professionals ${ }^{4}$.

The Brazilian Federal Council of Phonoaudiology regulates the use of telehealth strategies. The first regulation was published in 2013, with changes made in 2020 excluding some limitations to the practice. Besides core professional activities, such services can also be used in teleconsultation and telemonitoring activities. Teleconsultation may involve the speech therapist or other health professional at one side, and the patient and another speech therapist at a distance, or even a consultation with patient and speech therapist, both at a distance - introduced in 2020. Telemonitoring, on the other hand, involves the remote monitoring of previously face-to-face attended patient ${ }^{5,6}$.

\footnotetext{
${ }^{1}$ Universidade Federal de Sergipe, Program in Health Technological Management and Innovation - São Cristóvão (SE), Brazil.

'Universidade Federal de Sergipe, Department of Speech Therapy - São Cristóvão (SE), Brazil.

${ }^{3}$ Universidade Federal de Sergipe, Department of Medicine - São Cristóvão (SE), Brazil.

${ }^{4}$ Universidade Federal de Sergipe, Department of Computation, - São Cristóvão (SE), Brazil.

*Corresponding author: brendaaraujo@yahoo.com.br

Conflicts of interest: the authors declare there are no conflicts of interest. Funding: none.

Received on October 27, 2020. Accepted on November 05, 2020.
} 
With regard to telehealth applied to phonoaudiology, there is a greater number of publications in audiology, with focus on both educational and patient assistance. Teleaudiology is the term used to designate the provision of hearing services at a distance, and it has been a promising area in the adaptation of prostheses and guidance to cochlear implant (CI) users? Audiology deals with audiological evaluation, diagnosis, and treatment of people with impaired auditory and vestibular function and the prevention of associated dysfunctions. The central focus of audiology is on hearing impairment and their relationship with communication disorders ${ }^{8}$. It provides therapies that involve adaptation of individual sound amplification devices (i.e., hearing aids) for people with partial hearing loss. In audiology, teleconsultation has been used in different areas ranging from diagnosis of hearing loss to rehabilitation process. The first reports of the use of teleconsultation to adapt hearing aids date from the 1990s, in a pilot program at the Mayo Clinic, Rochester, MN, USA. In this program, audiology professionals used remote controlled applications to perform the adjustments of hearing aid devices? .

We aimed to demonstrate that the telehealth management could be a new trend on audiological clinical assistance and to show the evidences of the use of telehealth in audiology care.

\section{METHODS}

We conducted an integrative review of the scientific literature. This method was chosen to identify the scientific basis for understanding the role of telehealth in audiological care, besides providing a synthesis of published studies, and allowing general conclusions on teleaudiology and a more complete understanding of the topic.

The leading question of this study was as follows: "What is the scientific evidence for the use of telehealth in audiology?" For this research, published studies on telehealth in audiology were used. The databases consulted were "Biblioteca Virtual em Saúde" - Virtual Health Library (BVS/VHL), PubMed, and Scientific Electronic Library Online (SciELO). The research was carried out in May 2020 and limited to studies published in full text versions, without language restrictions, within the last 10 years. We used English key words that are listed in Table 1, descriptors registered in the Health Sciences Descriptors (DeCS) and/or Medical Subject Headings (MeSH). For articles not available in electronic databases or for the data not available in

Table 1. Keywords of the search strategies.

[(Telehealth or eHealth or mobile health or telemedicine) and (audiology)] the articles included in this review, the authors were contacted to obtain the necessary information.

The articles identified by the initial search strategy were evaluated according to the following inclusion criteria: addressing telehealth in audiology care regardless of age and/or sex of subjects and methodological design. Articles that used telehealth tools for the training of professionals in the field and those that addressed the topics in other areas of speech therapy, review studies, editorials, and research notes and comments were excluded. Out of 1,312 articles, 945 were found in BVS/VHL, 195 in PubMed, and 172 in SciELO. From those articles, only 18 articles were selected for addressing the researched theme. Of these, nine articles were excluded, as they addressed telehealth in the context of speech therapy generally and in professional training. Finally, nine articles were included in this review (Figure 1).

Finally, after the final selection of the studies included in the analysis, the main information was gathered, and a descriptive analysis was performed.

\section{RESULTS}

Of the nine studies selected in this integrative review, two were carried out in Canada, two in Brazil, and the other five in Australia, the United States, South Africa, Germany, and India, respectively. These articles are summarized in Chart 1 with the authors' descriptions, year of publication, country, type of study, objectives, and conclusions.

For the qualitative synthesis of this review, four cross-sectional studies ${ }^{10-13}$, a case-control study ${ }^{14}$, a case $s^{1}{ }^{17}{ }^{15}$, a validation study ${ }^{16}$, and two accuracy studies ${ }^{17,18}$ were analyzed. The sample size of the studies included in this review ranged from $2^{15}$ to $42,697^{14}$.

In 2019, Hatton et al. ${ }^{10}$ examined telehealth-enabled auditory brain stem response (TH-ABR) in 50 babies with hearing loss, living in rural communities in a program provided by British Columbia. The authors concluded that the program is efficient when compared with the face-to-face assessments, in addition to optimizing the availability of audiology resources. The program also builds local service capacity and reduces costs for communities.

Schepers et al. ${ }^{11}$, through an observational study, evaluated the safety and feasibility of remote programming in CI users. The sample consisted of 25 children and 21 adults, users of CIs, submitted to adjustment sessions locally and remotely. The results of these two adaptation sessions were compared in terms of safety, impedance field telemetry (IFT), maximum comfortable level (MCL), threshold level (THR), audiometry, duration of adaptation, and speech comprehension. 
The authors concluded that remote follow-up adjustment is safe, feasible, and effective when compared to local adjustment for CI users of all ages.

Monica et al. ${ }^{12}$ evaluated the feasibility of school hearing screening using telehealth technology operated by a professional located in a hospital $400 \mathrm{~km}$ away. The results showed no significant difference between pure tone audiometry (PTA) and distortion product otoacoustic emissions (DPOAE) performed in person or by tele-hearing screening methods. The authors indicated that synchronous hearing screening services can be provided in schools using mobile devices through hotspots or dongle connectivity in places where Internet bandwidth is limited.

Another study ${ }^{14}$ evaluated the effectiveness of teleaudiology for hearing aid services through a retrospective case-control study

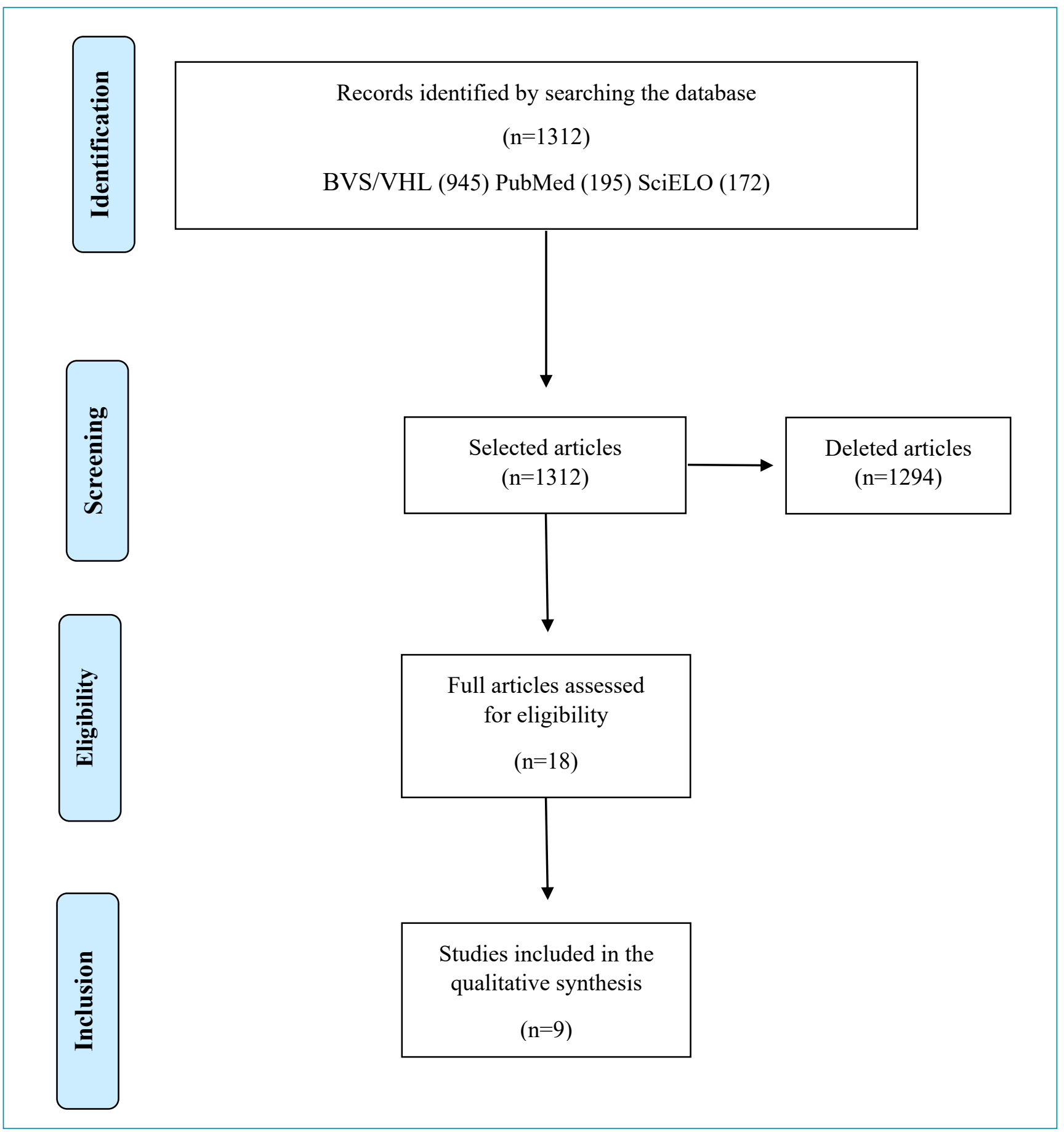

Figure 1. Flowchart of the literature search and screening process. 
Chart 1. Characteristics of the included studies.

\begin{tabular}{|c|c|c|c|}
\hline $\begin{array}{l}\text { Author/Year/ } \\
\text { Country }\end{array}$ & Study Design & Objective & Conclusion \\
\hline $\begin{array}{l}\text { Hatton et al. }{ }^{10} \text {, } \\
\text { 2019, Canada }\end{array}$ & Cross-sectional & $\begin{array}{l}\text { To describe the design/ } \\
\text { implementation of a telehealth- } \\
\text { enabled auditory brain stem response } \\
\text { (TH-ABR) program; summarize } \\
\text { equipment/procedures; report the } \\
\text { results of the TH-ABR program. }\end{array}$ & $\begin{array}{l}\text { TH-ABR is efficient, accurate, valued } \\
\text { by parents, optimizes the availability } \\
\text { of audiology resources, creates local } \\
\text { service capacity, and reduces costs for } \\
\text { communities in Northern British Columbia. }\end{array}$ \\
\hline $\begin{array}{l}\text { Schepers et al. }{ }^{11} \text {, } \\
\text { 2019, Germany }\end{array}$ & Cross-sectional & $\begin{array}{l}\text { To evaluate the safety and feasibility } \\
\text { of remote programming in cochlear } \\
\text { implant (CI) users for all ages. }\end{array}$ & $\begin{array}{l}\text { Remote tracking adjustment is } \\
\text { safe, feasible, and effective for } \\
\text { local adjustment for } \mathrm{Cl} \text { users. A } \\
\text { more extensive adoption of remote } \\
\text { adjustment can allow many } \mathrm{Cl} \text { users } \\
\text { greater access to clinics and greater } \\
\text { benefits from the use of } \mathrm{Cl} \text {. }\end{array}$ \\
\hline $\begin{array}{l}\text { Samelli et al. }{ }^{18} \text {, } \\
2018 \text {, Brazil }\end{array}$ & Accuracy study & $\begin{array}{l}\text { To evaluate the performance of a } \\
\text { tablet-based teleaudiometry method } \\
\text { for automated hearing screening of } \\
\text { schoolchildren by comparing the results } \\
\text { of various hearing screening approaches. }\end{array}$ & $\begin{array}{l}\text { The highest diagnostic values were } \\
\text { generally obtained by the automated } \\
\text { method of hearing screening (including } \\
500 \mathrm{~Hz} \text { ). The application, developed } \\
\text { for the tablet, proved to be a valuable } \\
\text { hearing screening tool for use in } \\
\text { schoolchildren. Therefore, we suggest } \\
\text { that this hearing screening protocol has } \\
\text { the potential to improve the provision } \\
\text { of asynchronous teleaudiology services. }\end{array}$ \\
\hline $\begin{array}{l}\text { Monica et al. }{ }^{12} \text {, } \\
2016 \text {, India }\end{array}$ & Cross-sectional & $\begin{array}{l}\text { To evaluate the feasibility of school } \\
\text { hearing screening using telehealth } \\
\text { technology operated by a professional } \\
\text { located in a hospital } 400 \mathrm{~km} \text { away. }\end{array}$ & $\begin{array}{l}\text { Synchronous hearing screening } \\
\text { can be provided in schools using } \\
\text { mobile device hotspots or dongle } \\
\text { connectivity in places where Internet } \\
\text { bandwidth is restricted. }\end{array}$ \\
\hline $\begin{array}{l}\text { Pross et al. }{ }^{14}, \\
\text { 2016, United } \\
\text { States }\end{array}$ & $\begin{array}{l}\text { Case-control, } \\
\text { retrospective }\end{array}$ & $\begin{array}{l}\text { To evaluate the effectiveness of } \\
\text { teleaudiology (TA) for hearing aid services. }\end{array}$ & $\begin{array}{l}\text { Assistance through TA and conventional } \\
\text { care to provide hearing aid services to } \\
\text { veterans is comparable, as both are } \\
\text { highly effective based on the results of } \\
\text { the International Outcome Inventory } \\
\text { for Hearing Aids (IOI-HA) results. The } \\
\text { non-inferiority of TA suggests that its } \\
\text { adoption by non-veterans can improve } \\
\text { access and preserve high satisfaction. } \\
\text { The financial impact of migration on TA } \\
\text { will require future econometric analysis. }\end{array}$ \\
\hline $\begin{array}{l}\text { Rourke et al. }{ }^{13}, \\
\text { 2016, Canada }\end{array}$ & $\begin{array}{l}\text { Cross-sectional } \\
\text { and prospective }\end{array}$ & $\begin{array}{l}\text { To determine the prevalence of hearing } \\
\text { loss in children aged } 4-11 \text { years; test } \\
\text { and demonstrate the use of the tablet } \\
\text { audiometer as a portable hearing test } \\
\text { device in children in a remote location. }\end{array}$ & $\begin{array}{l}\text { A total of } 14.8 \% \text { children tested } \\
\text { positive for hearing loss based on our } \\
\text { interactive audiometer for tablets. } \\
\text { The audiometer for tablets was } \\
\text { time-efficient and largely language- } \\
\text { independent. This test is valuable for } \\
\text { providing the necessary hearing health } \\
\text { care for high-risk populations in rural } \\
\text { and remote areas where audiology } \\
\text { services are not available. }\end{array}$ \\
\hline
\end{tabular}


Chart 1. Continuation.

\begin{tabular}{|c|c|c|c|}
\hline $\begin{array}{l}\text { Author/Year/ } \\
\text { Country }\end{array}$ & Study Design & Objective & Conclusion \\
\hline $\begin{array}{l}\text { Blamey et al. }{ }^{17} \text {, } \\
2015 \text {, Australia }\end{array}$ & Accuracy study & $\begin{array}{l}\text { To evaluate the effectiveness of an } \\
\text { online speech perception test (SPT) } \\
\text { for measuring hearing and adjusting } \\
\text { the hearing aid in comparison with } \\
\text { conventional methods. }\end{array}$ & $\begin{array}{l}\text { SPT is an effective tool for the detection } \\
\text { and measurement of hearing loss and } \\
\text { the adaptation of hearing aids. The } \\
\text { use of SPT reduces costs and increases } \\
\text { the effectiveness of adjusting the } \\
\text { hearing aid, enabling a sustainable } \\
\text { teleaudiology business model. }\end{array}$ \\
\hline $\begin{array}{l}\text { Penteado } \\
\text { et al. }{ }^{15}, 2013, \\
\text { Brazil }\end{array}$ & Case study & $\begin{array}{l}\text { To describe a case of remote } \\
\text { adaptation between two cities, } \\
\text { with a literature review. }\end{array}$ & $\begin{array}{l}\text { Remote adjustment of hearing aids is } \\
\text { possible over the Internet, in addition } \\
\text { to providing additional technical } \\
\text { training for a remote center on } \\
\text { assembly procedures. This technological } \\
\text { approach can help the government } \\
\text { to promote public policies in hearing } \\
\text { rehabilitation, as patients can be } \\
\text { motivated to keep using hearing aids } \\
\text { with the option of asking for help in } \\
\text { the comfort of their own homes. }\end{array}$ \\
\hline $\begin{array}{l}\text { Swanepoel } \\
\text { et al. }{ }^{16}, 2010, \\
\text { South Africa }\end{array}$ & Validation study & $\begin{array}{l}\text { To validate remote pure tone audiometric } \\
\text { tests performed in North America on } \\
\text { individuals from South Africa. }\end{array}$ & $\begin{array}{l}\text { It may be possible to expand the reach } \\
\text { of hearing services in remote and } \\
\text { underserved regions of the world. }\end{array}$ \\
\hline
\end{tabular}

with 42,697 veteran patients who received hearing aids. The main measures of outcomes were analyzed through a seven-item questionnaire that used to assess the effectiveness of the hearing aid (7-35 points, in which the highest scores are the most favorable). Among veterans who received hearing aids and completed the questionnaire, 1,009 received teleaudiology care and 41,688 received conventional care (in person). Although the comparison between groups showed a statistically significant difference $(\mathrm{p}<0.0001, t$-test $)$, mainly due to the large sample size, it was not clinically significant. The authors concluded that teleaudiology and conventional meetings are highly effective based on the results of the questionnaires. The non-inferiority of teleaudiology suggests that its adoption by non-veterans can improve access to other population groups and preserve high levels of satisfaction.

The prevalence of hearing loss in children aged 4-11 years was studied by Rourke et al. ${ }^{13}$ The authors also tested and demonstrated the use of the tablet audiometer as a portable hearing test device in children in a remote location. Of the studied population, $14.8 \%$ had hearing loss based on the interactive audiometer for tablets. The authors suggested that the tablet audiometer is an efficient and valuable tool for providing the necessary hearing health care for high-risk populations in rural and remote areas where audiology services are generally unavailable.
In our review, two studies were found ${ }^{17,18}$ addressing the accuracy of remote care in audiology. Blamey et al. ${ }^{17}$ evaluated the effectiveness of an online speech perception test (SPT) for measuring hearing aids and adjusting hearing aids compared with conventional methods. The research provided evidence that the online SPT can be considered an effective tool to detect and measure hearing loss and to adapt hearing aids. This test also reduces costs and increases the effectiveness of adjusting the hearing aid, enabling a sustainable teleaudiology business model. Following the same reasoning, the study by Samelli et al. ${ }^{18}$ aimed to evaluate the performance of a tablet-based teleaudiometry method for automated hearing screening in schoolchildren by comparing the results of hearing screening approaches. The authors concluded that the application developed for the tablet was proved to be a valuable hearing screening tool for use in school-aged children. Therefore, the authors suggested that this hearing screening protocol has the potential to improve the provision of teleaudiology services.

The research by Swanepoel et al. ${ }^{16}$ evaluated the validity of PTA tests. The study was carried out in individuals from South Africa. The results suggest that the thresholds for faceto-face and remote audiometry differed by $10 \mathrm{~dB}$ in only $4 \%$ of cases. The limits of agreement between the two techniques were $28-7 \mathrm{~dB}$, respectively, with a $90 \%$ confidence interval 
of $25-5 \mathrm{~dB}$, respectively. The authors concluded that it is necessary to use strategies to expand the scope of audiological services in remote and underserved regions of the world.

Penteado et al. ${ }^{15}$ described three patients who had their hearing aids adapted remotely with procedures being made between two different cities. The study points out that remote installation of hearing aids may be possible over the Internet. This technological approach can help the government to promote public policies in hearing rehabilitation, as patients can be motivated to keep using hearing aids with the option of asking for help from the professional from their own homes.

\section{DISCUSSION}

This integrative review analyses the following aspects: the accessibility to audiological assistance and the comparison between traditional strategies and the remote form of assistance, both in terms of effectiveness and cost.

The expansion of the scope of audiological services and the consequent improvement of access to audiological care through the use of telehealth are the factors highlighted by all authors listed in this review.

Hatton et al. ${ }^{10}$, Pross et al. ${ }^{14}$, and Blamey et al. ${ }^{17}$ emphasized the cost reduction for communities that receive remote services and the convenience it brings to patients similar to services located closer to their homes. According to Penteado et al. ${ }^{15}$, this contributes to better treatment success rates. It is important to note that most hearing aid users are elderly people with mobility issues or the need for a companion or caregiver during clinical assessments. These facts have potential impacts on therapeutic adherence.

Despite the benefits resulting from care assisted by communication technology, Pross et al. ${ }^{14}$ pointed out the loss of physical interaction between health care professional and patient as a possible negative impact of this model on health service delivery. In fact, the concern with the efficiency of the dialogue between these actors permeates remote evaluations where non-verbal aspects of communication, such as touch and body expression, can make the patient feel "robotic" and "artificial"19.

Among the studies comparing face-to-face care and remote assistance, there was an agreement about the safety, feasibility, and efficacy of remote CI programming activities ${ }^{11}$, hearing screening $^{10,12,16}$, and adaptation/monitoring of hearing implants ${ }^{14,17}$.

The use of a portable device (tablet) for audiometric tests was carried out in two studies ${ }^{13,18}$, both reporting efficiency and feasibility in hearing screening tests. In the study by Samelli et al. ${ }^{18}$, 244 Brazilian children were included, and in the study by Rourke et al. ${ }^{13}, 218$ Canadian children were included. Despite dealing with different countries and methodologies, the two studies proved that the use of portable devices is a valuable tool for screening of school-aged children, with practical and efficient uses. It is of great value to highlight the importance of screening in early detection and intervention to minimize the impact of hearing loss on the development and educational achievements of children.

Still, with regard to hearing screening, the study by Monica et al. ${ }^{12}$, carried out on Indian children aged between 5 and 8 years, showed that face-to-face screening compared with videoconference in the school environment had a concordance of 87-97\%, which confirms the feasibility of applying teleaudition for screening.

Schepers et al. ${ }^{11}$ concluded that remote CI programming and its adjustments are safe and effective when compared to local care, with no significant differences. Zumpano et al. ${ }^{20}$ studied the benefits and limitations for the implementation of remote CI programming and concluded that teleaudiology provides the decentralization of health services and cost reduction, being a viable practice. Although there is a 10 -year difference between the two studies, their results reinforce possible benefits, showing that remote CI programming is feasible. Nowadays, the greater accessibility to technologies, the global Internet revolution, and the growing implementation of cellular networks make the practice of teleaudiology increasingly possible. In addition, it is worth noting that during the current coronavirus disease 2019 (COVID-19) pandemic, in which the safest approach requires social distancing, the teleaudiology is an effective tool for providing care to patients with CI.

Hatton et al. ${ }^{10}$ studied the TH-ABR for the pediatric population in a remote location and concluded that the TH-ABR program was adequate, sustainable, and scalable. In a similar study, Ramkumar et al. ${ }^{21}$ compared a pediatric hearing screening program, integrating an $\mathrm{ABR}$ diagnostic test using a telemedicine and a face-to-face approaches. The authors concluded that this telehealth model has improved follow-up of patients compared with the face-to-face model, making it possible to provide care to people living in remote locations. This type of service reduces disparities between urban and rural populations, frequently with limited access to health care resources.

Regarding the audiological evaluation through the audiometry exam, Swanepoel et al. ${ }^{16}$ stated that there were no clinically significant differences between remote audiometric testing and conventional face-to-face testing results, and they concluded that it may be possible to expand audiological services to remote and underserved regions in the world. Visagie et al. ${ }^{22}$ obtained hearing thresholds from 20 adults living in a rural community, with no significant difference in hearing threshold results determined in the conventional scenario and in the telemedicine strategy. Innovative ways of bringing hearing health services to people who live in places far from urban centers, often in need, should be encouraged. 


\section{CONCLUSION}

This review highlights successful experiences in teleaudiology in programming CIs and adapting hearing aids, as well as in screening hearing disorders and validating instruments for this purpose. Despite the small number of studies, we identified that telehealth in audiology is a viable and efficient strategy, facilitating access to audiological services, with potential for cost reduction when compared to traditional care strategies. The changes in the Brazilian legal framework for the use of telehealth with the COVID-19 pandemic, in addition to cost effectiveness, showed that the use of telehealth is a new trend.

We emphasize the urgency in the adoption and development of new strategies, given the potential of telehealth in audiology and its consequent benefits, especially in countries with large territorial extension such as Brazil.

\section{AUTHORS" CONTRIBUTIONS}

TRCML: Conceptualization, Data Curation, Formal Analysis, Writing - Original Draft, Writing - Review \& Editing. LMS: Data Curation, Writing - Review \& Editing. MCHM: Data Curation, Writing - Review \& Editing. BCLA: Data Curation, Writing - Review \& Editing. MAS: Writing - Review \& Editing. AAO: Conceptualization, Supervision, Formal Analysis, Writing - Original Draft, Writing - Review \& Editing. SMS: Conceptualization, Supervision, Formal Analysis, Writing Original Draft, Writing - Review \& Editing.

\section{REFERENCES}

1. Silva EA. A telessaúde e seus impactos na formação continuada dos profissionais de saúde em rede. Em Rede - Revista de educação a distância. 2017 [cited on May 25, 2020];4(1):11629. Available from: https://www.aunirede.org.br/revista/index. php/emrede/article/view/151

2. Wen CL. Telemedicina e telessaúde - um panorama no Brasil. Informática Pública. 2008 [cited on May 25, 2020];10(2):715. Available from: http://pbh.gov.br/informaticapublica/ ANO10_N2_PDF/telemedicina_telesaude.pdf

3. Celes RS, Rossi TRA, Barros SG, Santos CML, Cardoso C. A telessaúde como estratégia de resposta do Estado: revisão sistemática. Rev Panam Salud Publica. 2018;42:e84. Portuguese. https://doi.org/10.26633/RPSP.2018.84

4. Brasil. Ministério da saúde. Portaria $n^{\circ} 2.546$, de 27 de outubro de 2011: Redefine e amplia o Programa Telessaúde Brasil, que passa a ser denominado Programa Nacional Telessaúde Brasil Redes (Telessaúde Brasil Redes). 2011 [cited on May 25, 2020] Available from: http://bvsms.saude.gov. br/bvs/saudelegis/gm/2011/prt2546_27_10_2011.html.

5. Brasil. Conselho Federal de Fonoaudiologia. Resolução CFFa n 427 de 01/03/2013: Dispõe sobre a regulamentação da Telessaúde em Fonoaudiologia e dá outras providências. 2013[cited on May 25, 2020]. Available from: https://www. legisweb.com.br/legislacao/?id=251914

6. Brasil. Conselho Federal de Fonoaudiologia. Resolução CFFa $n^{\circ}$ 580, de 20 de agosto de 2020: Dispõe sobre a regulamentação da Telefonoaudiologia e dá outras providências. 2020[cited on May 25, 2020]. Available from: https://www.fonoaudiologia.org.br/resolucoes/ resolucoes_html/CFFa_N_580_20.htm

7. Lucena AM, Couto EAB, Garcia VS, Alkmim MBM, Marcolino MS. Teleconsultorias de fonoaudiologia em um serviço público de telessaúde de larga escala. Rev CEFAC. 2016;18(6):1395-403. https://doi.org/10.1590/1982021620161860816

8. American Academy of Audiology. Scope of practice. Virginia: Yoko Co; 2004. [cited on May 26, 2020]. Available from: https:// www.audiology.org/practice-resources/practice-guidelinesand-standards/scope-of-practice/
9. Campos PD. Teleaudiology: analysis of professional/patient communication in the process of selecting and adapting individual hearing aids through teleconsultation [Tese]. São Paulo: Faculdade de Odontologia de Bauru, Universidade de São Paulo, 2016.

10. Hatton JL, Rowlandson J, Beers A, Small S. Telehealth-enabled auditory brainstem response testing for infants living in rural communities: the British Columbia Early Hearing Program experience. Int J Audiol. 2019;58(7):381-92. https://doi.org/ 10.1080/14992027.2019.1584681

11. Schepers K, Steinhoff HJ, Ebenhoch H, Böck K, Bauer K, Rupprecht $L$, et al. Remote programming of cochlear implants in users of all ages. Acta Otolaryngol. 2019;139(3):251-7. https://doi.org/10.1080/00016489.2018.1554264

12. Monica SD, Ramkumar V, Krumm M, Raman N, Nagarajan $R$, Venkatesh L. School entry level tele-hearing screening in a town in South India - Lessons learnt. Int J Pediatr Otorhinolaryngol. 2017;92:130-5. https://doi.org/10.1016/j. ijporl.2016.11.021

13. Rourke R, Kong DC, Bromwich M. Tablet audiometry in Canada's north: a portable and efficient method for hearing screening. Otolaryngol Head Neck Surg. 2016;155(3):473-8. https://doi.org/10.1177/0194599816644407

14. Pross SE, Bourne AL, Cheung SW. TeleAudiology in the veterans health administration. Otol Neurotol. 2016;37(7):847-50. https://doi.org/10.1097/MA0.0000000000001058

15. Penteado SP, Lima Ramos S, Battistella LR, Marone SAM, Bento RF. Adaptação à distância de próteses auditivas acústicas: a teleaudiologia aplicada na melhoria da condução das Políticas Públicas no Brasil. Int. Arch. Otorhinolaryngol. 2012;16(3):371-81. https://doi.org/10.7162/S180997772012000300012

16. Swanepoel W, Koekemoer D, Clark J. Intercontinental hearing assessment - a study in tele-audiology. J Telemed Telecare. 2010;16(5):248-52. https://doi.org/10.1258/ jtt.2010.090906

17. Blamey PJ, Blamey JK, Saunders E. Effectiveness of a teleaudiology approach to hearing aid fitting. J 
Telemed Telecare. 2015;21(8):474-8. https://doi. org/10.1177/1357633X15611568

18. Samelli AG, Rabelo CM, Sanches SGG, Martinho AC, Matas CG. Tablet-based tele-audiometry: automated hearing screening for schoolchildren. J Telemed Telecare. 2020;26(3):140-9. https://doi.org/10.1177/1357633X18800856

19. Reginato TTP, Ferrari DV. Teleaudiologia: comunicação profissional-paciente na programação e adaptação de aparelhos de amplificação sonora individuais via teleconsulta TT - Teleaudiology: professional-patient communication in hearing aid programming and fitting via teleconsultati. Audiol., Commun. Res. 2014;19(3):299-309. https://doi. org/10.1590/S2317-643120140003000015
20. Zumpano CE, Bevilacqua MC, Frederigue-Lopes NB, Costa OA. Remote programming of the cochlear implant systems. Rev Soc Bras Fonoaudiol. 2009;14(4):539-46. https://doi. org/10.1590/S1516-80342009000400019

21. Ramkumar V, Nagarajan R, Shankarnarayan VC, Kumaravelu S, Hall JW. Implementation and evaluation of a rural community-based pediatric hearing screening program integrating in-person and tele-diagnostic auditory brainstem response (ABR). BMC Health Serv Res. 2019;19(1):1. https://doi.org/10.1186/s12913-018-3827-x

22. Visagie A, Swanepoel W, Eikelboom RH. Accuracy of remote hearing assessment in a rural community. Telemed J E Health. 2015;21(11):930-7. https://doi.org/10.1089/tmj.2014.0243 